\title{
Postinfection Biological Control of Oomycete Pathogens of Pea by Burkholderia cepacia AMMDR1
}

\author{
K. Heungens and J. L. Parke
}

Department of Plant Pathology, University of Wisconsin, Madison 53706.

Current address of K. Heungens: Department of Bacteriology, University of Wisconsin, Madison 53706.

Current address of J. L. Parke: Department of Botany and Plant Pathology \& Department of Crop and Soil Science, Oregon State University,

ALS 3017, Corvallis 97331.

Accepted for publication 4 December 2000.

\begin{abstract}
Heungens, K., and Parke, J. L. 2001. Postinfection biological control of oomycete pathogens of pea by Burkholderia cepacia AMMDR1. Phytopathology 91:383-391.

Burkholderia cepacia AMMDR1 is a biocontrol agent that reduces Pythium damping-off and Aphanomyces root rot severity on peas in the field. We studied the effect of B. cepacia AMMDR1 on post-infection stages in the life cycles of these pathogens, including mycelial colonization of the host, production of oogonia, and production of secondary zoospore inoculum. We used Burkholderia cepacia 1324, a seed and rootcolonizing but antibiosis-deficient Tn5 mutant of B. cepacia AMMDR1, to study mechanisms of biological control other than antibiosis. $B$. cepacia AMMDR1 significantly reduced Pythium aphanidermatum postinfection colonization and damping-off of pea seeds, even when the bacte-

population densities at the site of zoospore inoculation. The antibiosisdeficient mutant, B. cepacia 1324 , had no effect on mycelial colonization of seeds or roots by Pythium aphanidermatum nor A. euteiches, suggesting that antibiosis is the primary mechanism of biological control. $B$. cepacia AMMDR1, but not B. cepacia 1324, reduced production of $A$. euteiches oogonia. This effect occurred even when the population size of B. cepacia AMMDR1 was too small to cause a reduction in lesion length early on in the infection process and may result from in situ antibiotic production. B. cepacia AMMDR1 had no effect on the production of secondary zoospores of $A$. euteiches from infected roots. The main effects of B. cepacia AMMDR1 on postinfection stages in the life cycles of these pathogens therefore were reductions in mycelial colonization by Pythium aphanidermatum and in formation of oogonia by A. euteiches. No mechanism other than antibiosis could be identified.
\end{abstract} ria were applied $12 \mathrm{~h}$ after zoospore inoculation. B. cepacia AMMDR1 also significantly reduced colonization of taproots by Aphanomyces euteiches mycelium, but only when the bacteria were applied at high
Additional keywords: oospores, plant growth-promoting rhizobacteria, rhizoplane.
Pythium spp. and Aphanomyces euteiches are important oomycete pathogens of pea (Pisum sativum L.) in North Central United States, as well as in many pea-growing areas worldwide $(10,41)$. Pythium spp., especially Pythium ultimum, Pythium irregulare, and Pythium sylvaticum, can be responsible for inadequate stand establishment as a result of pre- and postemergence damping-off (12). Some disease resistance against Pythium spp. is available but it is linked to undesirable phenotypes such as altered seed color and shape $(7,12)$. Chemical control with pesticides such as captan, thiram, fenaminosulf, and metalaxyl is effective (12), but there is growing public concern with the application of chemical pesticides. For captan, which has well-demonstrated mutagenic and carcinogenic effects $(2,37,53)$, this concern may be valid. Metalaxyl is less toxic than captan (34) but its use might not be sustainable as indicated by the emergence of metalaxyl-resistant oomycetes in the genera Phytophthora, Bremia, Pseudoperonospora, and Pythium $(35,55)$.

The second oomycete pathogen, A. euteiches Drechs., causes Aphanomyces root rot, the most serious yield-decreasing disease of peas in the Great Lakes area $(10,41)$ and in several European countries (45; E. Wicker, personal communication). It is also one of the more important pea diseases in the Pacific Northwest (25) and in several other pea-growing areas in the United States (41). The chemical pesticide hymexazol controls A. euteiches $(44,61)$ but is not registered in the United States (34). Dinitramine and

Corresponding author: J. L. Parke; E-mail address: Jennifer.Parke@ orst.edu

Publication no. P-2001-0118-01R

(C) 2001 The American Phytopathological Society trifluralin herbicides have suppressive nontarget effects on Aphanomyces root rot $(9,13)$ but are not economically feasible. Some control can be obtained after incorporation of certain crucifers as green manures $(36,58)$ or through intercropping of oats (17) but these cultural practices are usually not cost-effective or are impractical in a commercial cropping scheme. Although considerable progress has been made in breeding for resistance against this pathogen $(5,22,23,28)$, resistance is not always consistent, possibly due to variability in virulence and aggressiveness in the pathogen population (31). Aphanomyces root rot is currently controlled through crop rotation. Once a soil is infested with $A$. euteiches, long rotations to nonsusceptible hosts are required, because oospores, the pathogen's resting structures, may survive up to 10 years (41). Suspected high-risk soils are usually rated for their potential for root rot in a greenhouse assay to determine if it is safe to plant peas (41).

Successful biological control of these pathogens is desirable for Pythium because of the health concerns associated with chemical pesticides and a potentially more sustainable control; for Aphanomyces, biological control would offer some form of control other than avoidance. A control practice that would reduce the number of oospores could also reduce the length of the rotation once a soil is infested with A. euteiches.

Burkholderia cepacia AMMD was selected for its biocontrol potential against Pythium damping-off and Aphanomyces root rot of peas (43). When applied to seeds, it successfully controlled Pythium damping-off in growth chamber as well as in field experiments $(3,19,42,43)$. B. cepacia AMMD also successfully controlled Aphanomyces root rot in growth chamber experiments (43) and to a minor extent in the field $(3,19)$. 
Although B. cepacia AMMD shows promise for the control of these diseases in the field, it is not known what stages in the life cycle of the pathogens it affects and what mechanisms are involved. Increasing our understanding of these interactions could lead to targeted strategies to improve the extent, the consistency, and the long-term efficacy of the biocontrol agent. The effect of $B$. cepacia AMMDR1 on pre-infection stages in the life cycles of these pathogens was reported separately (14). This paper focuses on postinfection interactions, which, to our knowledge, have not specifically been addressed in biocontrol literature. The postinfection interactions studied were mycelial colonization of the host, production of asexual reproductive structures (zoosporangia and zoospores), and production of sexual reproductive structures (oogonia). Effects on reproductive structures may have implications on the epidemiology of these soilborne diseases.

The objectives of this paper were to (i) develop assays for in situ quantification of the pathogenic structures involved; (ii) determine which structures B. cepacia AMMDR1 affects; and (iii) determine the role of antibiosis in the observed effects. This last objective was accomplished by comparing the effects of $B$. cepacia AMMDR1 to those of B. cepacia 1324, an antibiosis-deficient but seed- and root-colonizing mutant of B. cepacia AMMDR1.

\section{MATERIALS AND METHODS}

Organisms. B. cepacia strain AMMD (NRRL B-23395) was isolated from the rhizosphere of peas grown in the Aphanomyces root rot nursery at Arlington Agricultural Experiment Station (Arlington, WI) (43). It has been referred to as Pseudomonas cepacia AMMD $(3,19,42,43)$, B. cepacia AMMD (20,52), and B. vietnamiensis AMMD (15), until the most recent reclassification in a new genomovar (VII) of the B. cepacia complex (4). B. cepacia AMMDR1 (NRRL B-23396), a spontaneous rifampicinresistant (100 ppm) mutant of $B$. cepacia AMMD with no known phenotypic differences other than antibiotic resistance, was used throughout this study. B. cepacia 1324 is a Tn5 mutant of $B$. cepacia AMMDR1 that no longer exhibits antibiosis in vitro against mycelial growth of Pythium (52). It contains a single Tn5 insertion, is not affected in siderophore and protease production, and has the same doubling time in the pea spermosphere as the parent strain (52). Pea seed coating with bacteria consisted of mixing seeds with bacteria scraped directly from 2-day-old tryptone glucose yeast extract (TGE) agar (39) cultures at a ratio of 20 seeds per plate, unless noted otherwise. Seeds were dried in a laminar flow cabinet for approximately $2 \mathrm{~h}$ before use in experiments, unless noted otherwise. Numbers of bacteria per seed were determined by 30 -s sonication and 10 -s vortexing in a $10-\mathrm{ml}$ water blank followed by plating of serial dilutions on TGE agar and were usually approximately $7.5 \log \mathrm{CFU}$ per seed. Bacterial cultures were started from $-80^{\circ} \mathrm{C}$ stocks.

A. euteiches Drechs. isolate 467 (NRRL 29624) was isolated from a diseased pea plant collected in Washara County, WI, and maintained on cornmeal agar (CMA) slants at $12^{\circ} \mathrm{C}$. Zoospores were produced as described previously (14). Pythium aphanidermatum (Edson) Fitzp., isolate BP-01 (NRRL 29623) originated from a diseased bean plant collected in New Mexico. A single zoospore culture was maintained on CMA slants at $12^{\circ} \mathrm{C}$. Zoospores were produced as described previously (14).

Pea seeds (Pisum sativum L. cv. Early Perfection 77) were obtained from Nunhems Seed Corp., Lewisville, ID. Seeds were surface disinfested for $5 \mathrm{~min}$ in $5.25 \% \mathrm{NaOCl}$ and rinsed at least four times in sterile type I Milli-Q water (Barnstead/Thermolyne, Dubuque, IA).

Curative effect of $B$. cepacia AMMDR1 against Pythium aphanidermatum. The curative effect of $B$. cepacia AMMDR 1 on a Pythium aphanidermatum infection was tested by applying the biocontrol bacterium to infected seeds and evaluating pathogen recovery and seedling emergence. Pythium aphanidermatum zoo- spore suspensions were diluted to $5 \times 10^{3} \mathrm{ml}^{-1}$ with Milli-Q water. Sets of 100 surface-disinfested and -redried seeds were placed in $300-\mathrm{ml}$ zoospore suspension and incubated at $28^{\circ} \mathrm{C}$. After $4-\mathrm{h}$ incubation, zoospore-inoculated seeds were either not treated or treated with B. cepacia AMMDR1 or B. cepacia 1324 at a ratio of 60 seeds per plate. There were four treatments, including control seeds immersed in Milli-Q water. Seeds were not allowed to dry and were planted in individual cells $(3 \times 4 \mathrm{~cm} ; 5 \mathrm{~cm}$ deep) of plastic trays (S-S812, Kord Co., Bramalea, Canada) in a randomized complete block design, trays were blocks. Each cell was filled in layers in the following way: $5 \mathrm{ml}$ of vermiculite, $10 \mathrm{ml}$ of silica sand, $5 \mathrm{ml}$ of deionized water, one seed from one of the four treatments, $10 \mathrm{ml}$ of silica sand, and $5 \mathrm{ml}$ of deionized water. The vermiculite, sand, and water were autoclaved prior to use. Flats were incubated at $28^{\circ} \mathrm{C}$ for 2 days at which point 24 seeds from each treatment were dug up and rinsed free of sand with tap water. The seed coat was removed and the two halves of the cotyledons were plated on $0.8 \%$ water agar with the flat side down. Seeds were checked for pathogen growth 1 and 2 days after plating. The rest of the seeds (48 per treatment) were further incubated at $28^{\circ} \mathrm{C}$ and scored for seedling emergence. Proportion data were analyzed with the chi-square test (59).

In a second version of this assay, the pathogen was allowed to colonize the seeds for a longer period before seeds were coated with bacteria. After removal from the zoospore suspension, seeds were placed between moist paper towels and incubated for an additional $12 \mathrm{~h}$ at $28^{\circ} \mathrm{C}$. At that point, bacteria were applied to the seeds and treated as described before. The assay was conducted twice, and experiments were treated as blocks. Unless noted otherwise, statistical analysis of all experiments was determined by analysis of variance (ANOVA) general linear model (version 12.1; Minitab Inc., State College, PA).

Effect of B. cepacia AMMDR1 and B. cepacia 1324 on pea root colonization by $A$. euteiches. Five seeds were placed in moistened paper towels (single folded). The paper towels were rolled up and placed in plastic test tube racks $(12 \times 30 \mathrm{~cm}, 4 \times$ 10 sections) that were placed in plastic dishwashing tubs $(30 \times$ $35 \mathrm{~cm}$ ) filled with Milli-Q water so the bottom $0.5 \mathrm{~cm}$ of the rolled towels were suspended in water. The tubs were placed in an incubator at $24^{\circ} \mathrm{C}$ for a $16-\mathrm{h}$ photoperiod. The water level in the tubs was adjusted daily to the original level. After 3 days, seedlings with straight taproots and, depending on the experiment, root lengths between 2.5 and $3.5 \mathrm{~cm}$ or between 3.0 and $4.0 \mathrm{~cm}$ were inoculated with zoospores of $A$. euteiches 467 . Inoculation consisted of immersing just the root tips $(5 \mathrm{~mm})$ for $1 \mathrm{~min}$ in approximately $10^{5}$ zoospores per $\mathrm{ml}$. Preliminary assays showed that with this timing, all roots became infected and showed spreading lesions 3 to 4 days later without killing the root primordia within the first 2 days of inoculation. To enable location of the original inoculation site during the rest of the experiment, roots were marked $5 \mathrm{~mm}$ above the root tip with a blue permanent marker that did not interfere with root growth or pathogen infection. Seedlings were placed in new rolled paper towels and incubated for 4 to 5 days more, at which point most or all of the following variables were measured to the nearest millimeter on each seedling: total root length, root growth since zoospore inoculation, lesion length upward and downward from the zoospore inoculation site, and length of root colonized by mycelium. To determine the extent of mycelial colonization, roots were separated from the rest of the seedling and cut in two sections at the inoculation point ( $5 \mathrm{~mm}$ down from the mark). These root sections were cleared and stained according to a modified protocol from Phillips and Hayman (47). Clearing consisted of placing the two root sections in $10 \% \mathrm{KOH}$ in separate test tubes for $4 \mathrm{~h}$ at $60^{\circ} \mathrm{C}$. Roots were rinsed twice with tap water for $5 \mathrm{~min}$ and once with $2 \% \mathrm{HCl}$ for $20 \mathrm{~min}$, then stained for $20 \mathrm{~min}$ at $60^{\circ} \mathrm{C}$ in $0.05 \%$ trypan blue in lactoglycerin (35\% lactic acid and $30 \%$ glycerin in water). Roots were rinsed and stored in lactoglycerin until observation. To 
measure the extent of mycelial colonization, both root sections were placed on a microscope slide and carefully squashed with a cover slip $(60 \times 20 \mathrm{~mm})$, which made the plant cells expand almost exclusively in the direction perpendicular to the root. The blue-stained hyphae were traced to the farthest locations above and below the point of inoculation in the upper and lower root sections, respectively, at $\times 100$ magnification with a compound microscope. The distance (in millimeters) was measured between the cut surface and those points. Individual roots were tracked throughout the experiment, allowing calculation of correlations between all variables. Lesion length was the preferred measure of pathogenic colonization by $A$. euteiches in most of the experiments because the length of root showing lesions was well correlated with the length of root over which hyphae had grown, and was much less laborious. Also, scanning electron microscopy of infected roots (data not shown) revealed that the hyphae also grew on the rhizoplane, which suggests that the length of root with lesions may be a more reliable representation of the length of root with pathogenic interactions than the length of root over which the pathogen can be observed. This relatively simple quantification is well correlated with quantification through polyclonal antibodies (24) and, unlike those serological techniques, can be performed on senescent tissue. Also, our technique can be used with a high resolution when little mycelial biomass is present, in contrast with detection methods through enzymatic activity (21).

To study the effect of $B$. cepacia AMMDR1 and B. cepacia 1324 on $A$. euteiches colonization of host roots, the biocontrol bacteria were applied to the seedlings in two different ways: either before or after inoculation with $A$. euteiches zoospores. The two methods allowed differentiation in time and location of the interaction between the pathogen and the biocontrol agent. In the first application method, B. cepacia AMMDR1 or B. cepacia 1324 were applied to the seeds as described previously. Nontreated seeds served as controls. With this method, bacteria were present on the root tips at the time of zoospore inoculation. Seedlings that received different bacterial treatments were incubated in separate tubs to avoid cross contamination. Root length and mycelial colonization were determined as described previously. This experiment was conducted three times with a minimum of 20 replicate roots per treatment.

In the second application method, roots, not seeds, were inoculated with bacteria 1 day after inoculation with zoospores. Seedlings were removed from the rolled towels, and entire root systems were immersed in a homogeneous bacterial suspension for $2 \mathrm{~min}$. The suspension consisted of one plate scraping per $20 \mathrm{ml}$ of $0.01 \mathrm{M}$ sterile potassium phosphate buffer at $\mathrm{pH} 7$, which corresponded with 10 to $10.3 \log \mathrm{CFU} \mathrm{m}{ }^{-1}$ of buffer. After treatment with bacteria (or the buffer control) seedlings were incubated in separate containers to avoid cross contamination. The experiment was conducted five times with a minimum of 20 replicate roots per treatment. Mycelial colonization of roots was determined 7 days after seeding as described previously.

Bacterial colonization of the pea rhizoplane in the rolled paper towel system. To determine if B. cepacia 1324 could colonize roots to the same extent as B. cepacia AMMDR1, bacterial populations were determined on root-inoculated and seed-inoculated seedlings. Seven days after seeding, bacterial populations were determined on 2 -cm root sections by 30 -s sonication and $10-\mathrm{s}$ vortexing of each section in a 5-ml water blank. Serial dilutions were made and appropriate dilutions were plated on $10 \%$ tryptic soy agar (TSA) and on trypan blue plus tetracycline plus rifampicin medium (TBTR) (20), a medium selective for rifampicinresistant B. cepacia strains, with a spiral plater (Spiral Biotech, Bethesda, MD). The experiments had four replicate sections and were conducted twice. In the version with root-dip inoculated seedlings, the experiment was also conducted after bacteria were inoculated with a 500-fold dilution of the bacteria, to determine whether B. cepacia 1324 could also colonize the roots to the same extent as B. cepacia AMMDR1 when starting populations were small. Data were analyzed with the mixed procedure of SAS (version 6.12; SAS Institute, Cary, NC), evaluating effects due to treatment, section, root, and the appropriate interaction.

The population size of $B$. cepacia AMMDR1 on the rhizoplane was also determined as a function of infection with A. euteiches. Three days after seeding B. cepacia AMMDR1-coated seeds, roots were inoculated or not inoculated with A. euteiches zoospores. Seven days after seeding, bacterial populations were determined on 1- or 2-cm root sections (depending on the experiment) as described previously. Data were analyzed by ANOVA.

Endophytic bacterial populations of pea roots grown in rolled paper towel system. Endophytic bacterial populations were determined to evaluate whether $B$. cepacia AMMDR1 can penetrate the roots and establish an endophytic population size large enough to interact directly or indirectly with A. euteiches hyphae. B. cepacia AMMDR1 was applied to seeds and incubated in paper towels as described previously. After 3 days, half of the seedlings were inoculated with A. euteiches zoospores. On day 7, endophytic populations of six infected and six noninfected roots were determined with a modification of the protocol involving trituration of surface-sterilized roots (11). All assays were performed with the root sections starting $2 \mathrm{~cm}$ and ending $4 \mathrm{~cm}$ away from the seed, which roughly corresponds with the zone where lesions first appear after an A. euteiches infection. To determine rhizoplane populations, each section was sonicated in $5 \mathrm{ml}$ of water for $30 \mathrm{~s}$ and dilution plated on 10\% TSA and TBTR. The sections were separately surface sterilized by 10 -s immersion in $95 \% \mathrm{EtOH}$ and $3 \mathrm{~min}$ of gentle shaking in $1.05 \% \mathrm{NaOCl}$ containing a drop of Tween 80. After at least four rinses with sterile water, each section was transferred to a 5-ml water blank to check for rhizoplane sterility; they were sonicated for $30 \mathrm{~s}$, and 1-ml aliquots were transferred into nutrient broth plus yeast extract broth (NBY) (1) and incubated on a rotary shaker. With a sterile mortar and pestle, each root section was triturated in $1 \mathrm{ml}$ of sterile water and $0.1 \mathrm{ml}$ of $10^{-0}$ or $10^{-1}$ dilutions plated on TBTR and on $10 \%$ TSA plates. Only the counts from root sections that had negative sterility checks were taken into account. Results were compared with $t$ tests.

To compare whether endophytic colonization was different with $B$. cepacia AMMDR1 versus B. cepacia 1324 , the assay was repeated with six B. cepacia AMMDR1-treated and six B. cepacia 1324-treated roots. This experiment was conducted only with roots not infected with A. euteiches.

Spatial and temporal characteristics of A. euteiches oogonia production. Oogonia were quantified along infected roots various days after inoculation with $A$. euteiches zoospores to determine the location, the number, and the timing of oogonia formation. Methods were modified from Kraft and Boge (24).

Seedlings were grown in rolled paper towels and infected with A. euteiches as described previously. They were replaced in two overlapping paper towels so roots could grow to lengths of at least $15 \mathrm{~cm}$ before reaching the water level in the reservoir. Seedlings were further incubated and evaluated for the presence of oogonia $4,5,8,10$, and 12 days after zoospore inoculation. At each time point, taproots were cut into $1-\mathrm{cm}$ sections with the marked zoospore inoculation site as the reference point. The first cut was made on the inoculation point and there were four sections toward the seed and eight sections toward the root tip. Lateral roots were not included in the sections. For most seedlings, the uppermost section comprised at least a part of the hypocotyl. There were two replicates for each time point consisting of five bulked roots. For each replicate, root sections were placed in $5 \mathrm{ml}$ of $0.24 \%$ gluteraldehyde in capped test tubes and stored at $4^{\circ} \mathrm{C}$ until quantification of oogonia. Root sections and storage liquid were poured in a Tenbroeck tissue grinder (Kontes, Vineland, NJ) and macerated by 15 to 20 pestle movements. Care was taken to get a small-grained, uniform macerate independent of the section along the root. Mac- 
erate was diluted twofold, and $50 \mu \mathrm{l}$ was transferred to microtiter wells (96-well plate). Oogonia were allowed to settle for a couple of minutes and were counted by scanning the bottom of the wells with an inverted microscope at $\times 100$ magnification. We verified that the variance between subsamples was considerably smaller than the variance between samples. We also confirmed the general trend in the counts by microscopic observation of cleared and stained roots of the corresponding ages. In a second experiment, the presence of oogonia was also evaluated at 11, 14, and 17 days after inoculation with zoospores.

Effect of biocontrol bacteria on oogonia production. To determine whether B. cepacia AMMDR1 or B. cepacia 1324 could reduce production of oogonia, seeds were treated or not treated with B. cepacia AMMDR1 or B. cepacia 1324 , planted in rolled towels, inoculated with $A$. euteiches zoospores, and re-incubated in double paper towels as described previously. Five and twelve days after zoospore inoculation, numbers of oogonia were determined. There were four replicates for each time point with five roots per replicate. The experiment was conducted twice. The experiment was also conducted with root-applied instead of seed-applied bacteria. In that case, there were three replicates for each time point, consisting of 10 roots per replicate. In both cases, results were analyzed by ANOVA and least significant difference (LSD) tests.

To determine the location of oogonia within cross sections of infected roots and to determine if the bacteria influence the site of oogonia production, cross sections were made from the roots 12 days after zoospore inoculation. Sections were made from the root area starting at the former zoospore inoculation point and ending approximately $1 \mathrm{~cm}$ toward the root tip. Freehand sections, approximately $150 \mu \mathrm{m}$ thick, were made after placing the roots in a groove between two carrot halves (38). Sections were carefully transferred to microtiter wells that were cleared and stained as described previously. The sections were observed with an inverted microscope and scored for presence or absence of oogonia in cortex and vascular cylinder. At least five sections from at least four roots were scored for each treatment.

Dose-response effect of $B$. cepacia AMMDR1 on mycelial colonization of the host and oogonia production. Roots infected with A. euteiches were dip-inoculated in decreasing concentrations of B. cepacia AMMDR1 to determine what population of the biocontrol agent is required to affect root colonization and oogonia production by the pathogen. Roots were dipped in phosphate buffer (0.01 M, pH 7) or in a B. cepacia AMMDR1 cell suspen-

TABLE 1. Effect of Burkholderia cepacia AMMDR1 and B. cepacia 1324 on pea seedling emergence and recovery of Pythium aphanidermatum from pea seeds, when applied varying times after inoculation with pathogen zoospores

\begin{tabular}{|c|c|c|c|c|c|}
\hline \multicolumn{2}{|r|}{ Treatment } & \multicolumn{2}{|c|}{ Emergence $^{v}$} & \multicolumn{2}{|c|}{ Pathogen recovery ${ }^{\mathrm{w}}$} \\
\hline Pathogen $^{x}$ & Bacteria & Short $^{\mathrm{y}}$ & Long $^{\mathrm{z}}$ & Short' & Long $^{\mathrm{Z}}$ \\
\hline - & - & 94 a & $88 \mathrm{a}$ & $0 \mathrm{a}$ & $0 \mathrm{a}$ \\
\hline+ & - & $0 \mathrm{c}$ & $5 \mathrm{c}$ & $100 \mathrm{c}$ & $88 \mathrm{c}$ \\
\hline+ & B. серасіа AMMDR1 & $46 \mathrm{~b}$ & $26 \mathrm{~b}$ & $33 \mathrm{~b}$ & $54 \mathrm{~b}$ \\
\hline+ & B. серасіа 1324 & $4 \mathrm{c}$ & $7 \mathrm{c}$ & $96 \mathrm{c}$ & $77 \mathrm{c}$ \\
\hline
\end{tabular}

${ }^{\mathrm{v}}$ Percentage of emerging seedlings (out of 48 seeds).

w Percentage of seeds (out of 24 ) with mycelial outgrowth of Pythium aphanidermatum upon plating cotyledons on water agar.

x Inoculation with Pythium aphanidermatum zoospores (+) or with water (-).

${ }^{y}$ The short pathogen incubation treatments consisted of 4-h incubation of seeds in zoospore suspension (or in water for negative control) before application of bacteria. Within each column, treatments indicated with the same letter are not significantly different at the 5\% level following paired chi-square tests.

${ }^{\mathrm{z}}$ The long pathogen incubation treatments consisted of an extra 12-h incubation of the zoospore-inoculated seeds between moist paper towels before treatment with bacteria. Data represent average of two experiments (experiments $=$ blocks). Within each column, values followed by the same letter are not significantly different $(P>0.05)$ according to least significant difference tests on the arcsin square root-transformed percentage values. sion of either $2 \times 10^{6}, 2 \times 10^{8}$, or $2 \times 10^{10} \mathrm{CFU} \mathrm{ml}^{-1}$ and reincubated in double rolled paper towels. Bacterial rhizoplane populations were determined on four randomly selected roots at $2 \mathrm{~h}$ after bacterial inoculation (4 days after seeding) and at 4 days after bacterial inoculation (7 days after seeding). Lesion length was measured on all roots 4 days after zoospore inoculation. Seedlings were chosen at random from each treatment 12 days after zoospore inoculation. Numbers of oogonia were determined, as described previously, in taproots that were longer than $12 \mathrm{~cm}$. There were five replicates and each replicate consisted of 10 bulked roots. Length of root showing lesions, total numbers of oogonia, and numbers of oogonia per unit of lesion were analyzed by ANOVA and LSD.

Production of secondary zoospore inoculum in A. euteiches. Seeds were planted in rolled paper towels, inoculated with zoospores, and re-incubated in paper towels as described previously. Five days after seeding, seedlings were randomly split into three groups and either root-dip inoculated in buffer, $B$. cepacia AMMDR1 or B. cepacia 1324 . Seedlings were re-incubated for approximately $30 \mathrm{~h}$ and removed from the rolled towels. Roots were cut off $5 \mathrm{~mm}$ above the mark and placed in 10-ml test tubes filled with sterile lakewater (14) up to the mark. This stimulated formation of zoosporangia from roots. Test tubes were incubated at $20^{\circ} \mathrm{C}$ for $12 \mathrm{~h}$, after which the lakewater was replaced with fresh, sterile lakewater to stimulate zoospore release. Approximately $24 \mathrm{~h}$ later, test tubes were vortexed for $30 \mathrm{~s}$ and sonicated for $30 \mathrm{~s}$ to encyst zoospores and bring them into suspension. Aliquots of this suspension $(10$ and $100 \mu \mathrm{l})$ were transferred to microtiter wells and $100 \mu \mathrm{l}$ of $4 \%$ gluteraldehyde and $5 \mu \mathrm{l}$ of trypan blue stain in lactoglycerin were added to each well. Spores were allowed to settle and were counted by scanning the bottom of the wells with an inverted microscope at $\times 100$ or $\times 200$ magnification. The total number of zoospores produced from each root was determined by multiplying the number of zoospores per sample volume by the volume of lakewater in each tube. There was a minimum of 20 replicate roots for each treatment, and the experiment was conducted twice. Results were analyzed by ANOVA.

\section{RESULTS}

Curative effect of $B$. cepacia AMMDR1 against Pythium aphanidermatum. Seedling emergence increased substantially

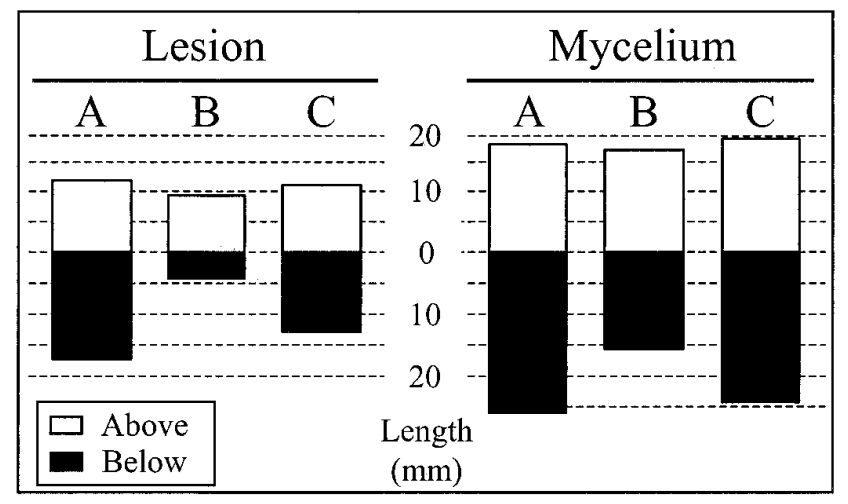

Fig. 1. Effect of bacterial treatment on lesion length and length of root with mycelium of Aphanomyces euteiches. Treatments: $\mathrm{A}=$ no inoculation; $\mathrm{B}=$ Burkholderia cepacia AMMDR1; and C = B. cepacia 1324 . White and black blocks refer to the parts of the root above and below the zoospore inoculation site (length $=0$ ), respectively. Data are from one representative experiment out of five. For the data on total lesion length, $\mathrm{LSD}_{0.05}$ and $\mathrm{LSD}_{0.01}$ were 4.5 and $6.0 \mathrm{~mm}$, respectively. For the data on total length of root with mycelium, $\mathrm{LSD}_{0.05}$ and $\mathrm{LSD}_{0.01}$ were 6.4 and $8.5 \mathrm{~mm}$, respectively. Within each group, the only significant differences (at both levels) were between the treatment with B. cepacia AMMDR1 and each of the other treatments. 
from 0 to $46 \%$ when seedlings were treated with $B$. cepacia AMMDR1, $4 \mathrm{~h}$ after inoculation with Pythium aphanidermatum (Table 1). When the pathogen was allowed to incubate an extra $12 \mathrm{~h}$ on the seeds before bacteria were applied, seedling emergence was increased from 5 to $26 \%$. In both cases, no statistically significant effect was observed after seed coating with the antibiosis-deficient strain, B. cepacia 1324 . B. cepacia AMMDR1, but not $B$. cepacia 1324, significantly decreased pathogen recovery from the seeds. This effect was greater when $B$. cepacia AMMDR1 was applied shortly after inoculation with Pythium aphanidermatum (Table 1).

Effect of B. cepacia AMMDR1 and B. cepacia 1324 on pea root colonization by $A$. euteiches. A dip inoculation of $A$. euteiches-infected roots in B. cepacia AMMDR1 resulted in a significant reduction of lesion length and a reduction in the length of root colonized with $A$. euteiches mycelium. No reductions were observed when roots were dipped in B. cepacia 1324 (Fig. 1). In contrast with root-dip inoculation, coating the seeds with bacteria did not lead to a significant reduction in lesion length (data not shown).

Bacterial colonization of the pea rhizoplane in the rolled paper towel system. B. cepacia AMMDR1 and B. cepacia 1324 colonized seedlings to the same extent 7 days after seeding, independent of whether they had been applied to the seed or to the root. The $P$ value for the factor "bacterial strain" was 0.65 when the bacteria were applied to the roots and 0.77 when the bacteria were applied to the seeds. There was no "root section" by bacterial strain interaction (the $P$ values were 0.29 and 0.74 for dipinoculated and seed-inoculated plants respectively). On dip-inoculated roots, both bacterial strains colonized the two $2-\mathrm{cm}$ root sections closest to the seed with approximately $10^{7} \mathrm{CFU}$ per section, whereas the next two sections were colonized with $10^{5}$ to $1.5 \times 10^{6} \mathrm{CFU}$ per section. On seed-inoculated roots, both bacterial strains colonized the two 2-cm root sections closest to the seed with $10^{6}$ to $4 \times 10^{6} \mathrm{CFU}$ per section, whereas the next two sections were colonized with $2 \times 10^{5}$ to $10^{6} \mathrm{CFU}$ per section. Even when bacteria were root-dip inoculated at 500-fold lower population densities, B. cepacia AMMDR1 and B. cepacia 1324 colonized the roots to the same extent on day 7 (the $P$ value for the factor bacteria was 0.28 ). Although bacterial populations were similar with the two inoculation methods 7 days after seeding, the population size of $B$. cepacia AMMDR1 near the root tip was approximately 1 log level larger on dip-inoculated plants versus seed-inoculated plants at 4 days after seeding (data not shown).

Infection of roots with $A$. euteiches resulted in up to $1 \log$ level higher total bacterial and B. cepacia AMMDR1 populations on the pea rhizoplane (Fig. 2). The difference between infected and noninfected roots was largest on the first two sections, which showed clear lesions by day 7 . In contrast with the results 4 days after seeding, B. cepacia AMMDR1 no longer dominated the rhizoplane; numbers of bacteria on TSA were significantly larger than on TBTR medium for three out of four sections. The proportion of the total bacteria that were B. cepacia AMMDR1 decreased on sections further from the seed, the original inoculation point.

Endophytic bacterial populations of pea roots grown in rolled paper towel system. The population size of endophytic bacteria in noninfected roots was $2.2 \log$ CFU per section $(53 \% \mathrm{~B}$. cepacia AMMDR1), versus $3.6 \log$ CFU per section $(70 \%$ B. cepacia AMMDR1) in infected roots $(P=0.047)$. Rhizoplane populations were approximately $5 \mathrm{log}$ levels higher than endophytic populations. When using the most stringent sterility checks, only one-third of the sections were negative and could be used for calculating internal populations. The endophytic population size of $B$. cepacia 1324 was not significantly different than that of $B$. cepacia AMMDR1 $(P=0.70)$.

Spatial and temporal characteristics of A. euteiches oogonia production. Oogonia production started 4 days after zoospore inoculation and increased until 12 to 14 days after zoospore in- oculation, when lesions had spread over the entire root system (data not shown). Final numbers of oogonia were 20,000 to 25,000 per seedling taproot (first $12 \mathrm{~cm}$ ). Most oogonia were located in the first few centimeters surrounding the inoculation site (5,000 to 6,000 oogonia per centimeter of root), especially in the direction of the root tip, but oogonia were present all the way to the root tip. Few to no oogonia were formed in the hypocotyl and stem of the plant ( 3 to $4 \mathrm{~cm}$ above the zoospore inoculation zone). Microscopical observation of cleared and stained roots confirmed timing and location of oogonia production.

Effect of biocontrol bacteria on oogonia production. Total numbers of oogonia per root, 12 days after inoculation with zoospores, were reduced by approximately $60 \%$ in treatments where B. cepacia AMMDR1 was applied, independent of whether the bacteria were applied to seeds or roots. No reduction was observed in treatments with B. cepacia 1324 (Table 2). Onset of oogonia production was slower in the experiment with bacteria applied to roots, but final numbers were similar to those in the experiment with bacteria applied to seeds. Figure 3 shows the numbers of oogonia in root sections for the assay in which bacteria were seed-applied. Numbers of oogonia were reduced from $3 \mathrm{~cm}$ above to $3 \mathrm{~cm}$ below the zoospore inoculation point.

Oogonia were present throughout radial sections of roots infected with A. euteiches; large numbers were present in the cortex as well as inside the vascular cylinder (data not shown). Cross sections of infected roots that were treated with $B$. cepacia AMMDR 1 contained few to no oogonia in 6 out of 10 roots. In two out of the four roots that still contained oogonia, numbers were reduced in the cortex but not in the stele. No differences in numbers of oogonia were observed between B. cepacia 1324treated and -nontreated roots.

Dose-response effect of B. cepacia AMMDR1 on mycelial host colonization and oogonia production. Dipping roots in suspensions with decreasing concentrations of $B$. cepacia AMMDR1 resulted in corresponding decreases in numbers of $B$. cepacia AMMDR1 on the rhizoplane of the roots (Fig. 4). The

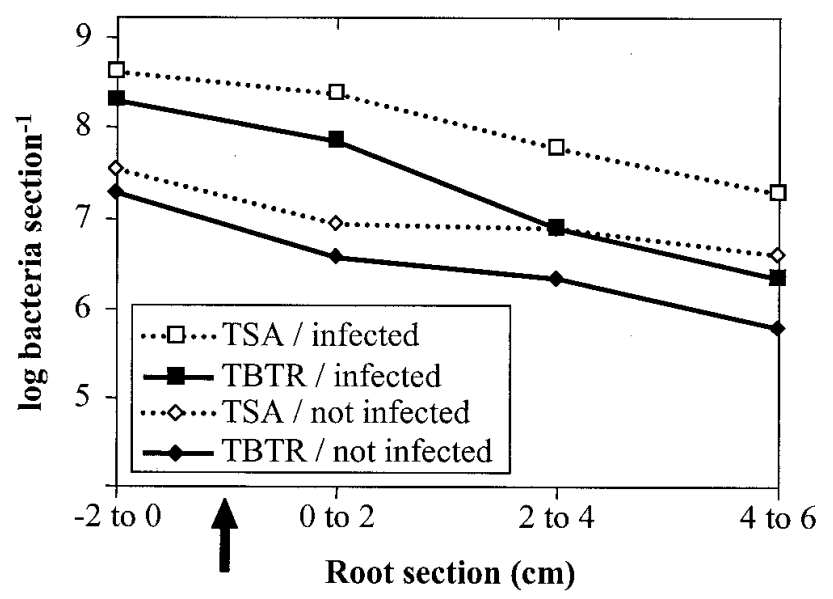

Fig. 2. Rhizoplane populations of total bacteria (plated on $10 \%$ tryptic soy agar [TSA]) and Burkholderia cepacia AMMDR1 (plated on trypan blue plus tetracycline plus rifampicin medium [TBTR]) on roots infected or not infected with Aphanomyces euteiches 7 days after seeding. B. cepacia AMMDR1 was applied to seed at $3.4 \times 10^{7}$ per seed. Roots were inoculated with zoospores 3 days after seeding. Root sections refer to centimeters above (negative) or below (positive) the location of the root tip at the time of zoospore inoculation (arrow). The effect of inoculation of the pathogen on colonization of roots by B. cepacia AMMDR 1 and by total bacteria was analyzed by means of two-way analysis of variance within each root section. The $P$ values for the factor infection were $0.001,0.001,0.001$, and 0.045 for the consecutive root sections (left to right). The $P$ values for the factor bacteria (plating medium) were $0.072,0.037,0.001$, and 0.008 for the consecutive root sections (left to right). The interaction factor was not significant for any section. 
three bacterial inoculation levels resulted in root populations that were significantly different $(P<0.001$ at each time point). Differences in rhizoplane populations of $B$. cepacia AMMDR1 became smaller after 4 days incubation, especially between the upper two inoculation levels. Although the highest absolute population densities were observed following root-dip inoculation in $10^{10}$ or $10^{8} \mathrm{CFU} \mathrm{ml}^{-1}$, the increase in population size was largest with the $10^{6} \mathrm{CFU} \mathrm{m}{ }^{-1}$ inoculation. The two sections closest to the zoospore inoculation site contained the highest number of bacteria.

Lesion length was only reduced when dipping roots in $10^{10} \mathrm{CFU} \mathrm{ml} \mathrm{m}^{-1}$ (Table 3). Overall numbers of oogonia were reduced $65 \%$ in the $10^{10} \mathrm{CFU} \mathrm{m} \mathrm{m}^{-1}$ treatment. The reduction in oogonia was most apparent in the sections spanning $1 \mathrm{~cm}$ above the zoospore inoculation site to $3 \mathrm{~cm}$ down from the zoospore inoculation site (data not shown). In contrast with the results on lesion length, numbers of oogonia were also significantly reduced in the $10^{8} \mathrm{CFU} \mathrm{ml} \mathrm{m}^{-1}$ treatment $(32 \%$ reduction when compared with the noninoculated control). The difference between the noninoculated control and the $10^{6} \mathrm{CFU} \mathrm{ml} \mathrm{m}^{-1}$ treatment was not statistically significant (Table 3 ).

Production of $A$. euteiches secondary zoospore inoculum. Numbers of zoospores produced from infected roots were not significantly reduced after root-dip inoculation with $B$. cepacia AMMDR 1 or $B$. cepacia 1324 in either of the two experiments $(P>0.05)$. In the first experiment, the average number of secondary zoospores (log scale) produced per root was 3.63, 3.64, and 3.66 for noninoculated roots, B. cepacia AMMDR1-inoculated roots, and $B$. cepacia 1324-inoculated roots, respectively. In the second experiment, the average number of zoospores released per root was 3.91, 3.51, and 3.78 for noninoculated roots, B. cepacia AMMDR1-inoculated roots, and B. cepacia 1324-inoculated roots, respectively. Average zoospore production was highly variable between roots in all treatments; the standard deviation was approximately $1.0 \mathrm{log}$ level in the first experiment, and approximately $0.65 \log$ levels in the second experiment.

\section{DISCUSSION}

B. cepacia AMMDR1 showed clear antagonistic effects against A. euteiches and Pythium aphanidermatum during certain postin-

TABLE 2. Total numbers of oogonia of Aphanomyces euteiches per taproot over time $^{\mathrm{X}}$

\begin{tabular}{lccccc}
\hline & \multicolumn{2}{c}{ Seed-applied } & & \multicolumn{2}{c}{ Root-applied } \\
\cline { 2 - 3 } \cline { 5 - 6 } Treatment & 5 days & 12 days & & 5 days & 12 days \\
\hline No bacteria & $2,451 \mathrm{a}$ & $21,845 \mathrm{a}$ & & 547 & $20,513 \mathrm{a}$ \\
B. cepacia AMMDR1 & $411 \mathrm{~b}$ & $8,615 \mathrm{~b}$ & & 160 & $11,947 \mathrm{~b}$ \\
B. cepacia 1324 & $2,548 \mathrm{a}$ & $20,482 \mathrm{a}$ & & 600 & $18,080 \mathrm{a}$ \\
& & & & & \\
$P$ value $^{\mathrm{y}}$ & 0.006 & $<0.001$ & & 0.06 & 0.008 \\
Root sections $^{\mathrm{z}}$ & -3 to +6 & -3 to +9 & & -3 to +6 & -4 to +10 \\
Roots/replicate & 5 & 5 & & 10 & 10 \\
Replicates & 4 & 4 & & 3 & 3 \\
\hline
\end{tabular}

${ }^{\mathrm{x}}$ Seedlings were either not treated with bacteria or treated with Burkolderia cepacia AMMDR1 or B. cepacia 1324. Bacteria were applied to the seeds or to roots. Bacteria scraped from 2-day-old tryptone glucose yeast extract agar cultures were applied to seeds before planting at a ratio of $10^{8} \mathrm{CFU}$ per seed or bacteria were applied by dip-inoculating roots in bacterial suspensions $\left(10^{10} \mathrm{CFU} \mathrm{ml}{ }^{-1}\right)$ for $4 \mathrm{~min}$. Five and twelve days indicates the number of days after zoospore inoculation of roots. Zoospores were inoculated 3 days after seeding in rolled paper towels. Within each column, means followed by the same letter are not significantly different $(P>0.05)$ following protected least significant difference tests on log-transformed number of oogonia per root.

y Observed $P$ values for test of equality of means based on analysis of variance of log-transformed total number of oogonia per root.

${ }^{\mathrm{z}}$ Portion of taproot (in centimeters) used for quantification of oogonia. Negative values refer to distance above the zoospore inoculation point (toward seed). Positive values refer to distance below the zoospore inoculation point (toward root tip). fection stages in their life cycles. There was no effect of $B$. cepacia 1324 in any of the interactions studied, suggesting that antibiosis was the main mechanism of biological control by $B$. cepacia AMMDR1. The nature of the antibiotic is still being determined through genetic and biochemical analysis, but it does not involve phenazines or 2,4-diacetylphloroglucinol (D. Weller, personal communication).

B. cepacia AMMDR1 reduced mycelial colonization of the host, especially by Pythium aphanidermatum, where $B$. cepacia AMMDR1 actually had a curative effect on a progressing infection. Although there are numerous reports of bacterial biocontrol agents reducing Pythium infection incidence (reviews by Martin and Loper, and Whipps and Lumsden in literature citations 33 and 63, respectively), this is the first report that an ongoing Pythium infection of true seeds is reduced by subsequent application of biocontrol bacteria. Application of a biocontrol agent after $P y$ thium infection is not practical, but it demonstrates the potential of biocontrol interactions during this stage in the life cycle of the pathogen. The window for protection against seed infection may be small; as many as $100 \%$ of the seed coats of peas may be infected with Pythium 12 h after planting. However, embryo colonization and death may be less than $5 \%$ until $24 \mathrm{~h}$ after planting (29). This leaves a window for postinfection biocontrol interactions. In order to maintain consistency with earlier work $(3,19,42,43)$, seed-applied bacteria were scraped from plates, which may have resulted in the application of the antibiotic with the cells. However, part of the biocontrol effect could still be due to in situ production of antibiotics, which can peak as soon as $12 \mathrm{~h}$ after planting on high-exuding seeds (26). If application of the preformed antibiotic with the biocontrol agent would increase protection during the first hours, similar to synergistic effects observed when applying biocontrol agents together with a lower dose of a chemical pesticide $(16,18)$, this may be a practice that deserves more attention for practical applications. Even if $B$. $c e$ pacia AMMDR1 cannot stop the invasion of the embryo, bacterial colonization and antibiotic production on the seeds could reduce the build up of secondary inoculum by the pathogen.

B. cepacia AMMDR1 also reduced A. euteiches mycelial colonization in the root but only when roots were dip-inoculated in a concentrated cell suspension. Root dipping in suspensions of

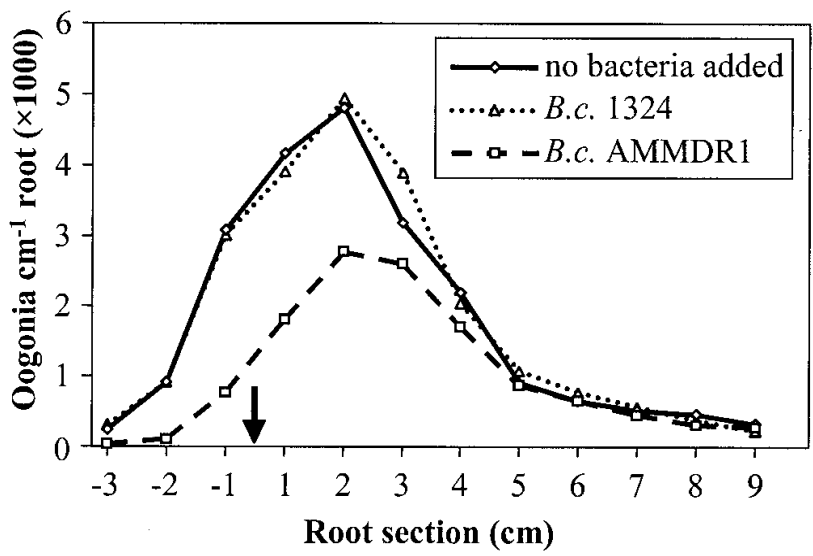

Fig. 3. Effect of seed treatment with Burkholderia cepacia AMMDR1 or $B$. cepacia 1324 on numbers of Aphanomyces euteiches oogonia in pea roots 12 days after inoculation with zoospores taken from average of two experiments. Section numbers refer to $1-\mathrm{cm}$ root sections toward the seed (negative) or toward the root tip (positive) with the arrow representing the location of the root tip at the time of zoospore inoculation. Differences between the B. cepacia AMMDR1 treatment and each of the other treatments were statistically significant $(P<0.05)$ in sections -3 through +2 according to least significant difference tests within each section and over the two experiments (blocks). No significant differences $(P>0.05)$ were observed between roots with no bacteria added and roots with $B$. cepacia 1324 in any of the sections. 
lower bacterial concentrations and seed-applying B. cepacia AMMDR1 did not result in reductions in lesion length. A threshold number of at least $10^{6} \mathrm{~B}$. cepacia AMMDR1 cells per centimeter of root at the site of mycelial growth appears necessary to reduce pathogen growth. Both root-dip inoculation in bacterial suspension of lower concentrations and seed inoculation resulted in lower numbers of bacteria near the root tip early on in the infection process. The threshold number may be required for in situ antibiotic production as a result of quorum sensing, or may be required for antibiotic production sufficient to affect the pathogen. Alternatively, a major proportion of the biocontrol activity may result from applying the preformed antibiotic with the bacterial cells when preparing the suspensions from plate scrapings. Further diluting the suspensions not only reduces the concentration of bacteria but also dilutes the antibiotic. Similarly, seed coating does not involve application of antibiotic to roots. A preliminary experiment designed to differentiate between these possibilities consisted of fractionating the bacterial suspension into "bacterial cells only" and "supernatant only" portions. It revealed that a part of the reduction in lesion length is indeed conferred by the supernatant.

It is unlikely that the inhibition of mycelial colonization of the host results from induced systemic resistance (ISR) (30) by the biocontrol agent. First, for root-dip-inoculated $B$. cepacia AMMDR1, the pathogen is inoculated before the biocontrol agent, eliminating the possibility that the biocontrol agent would induce resistance to the pathogen. Second, even if the bacteria were rootinoculated before the pathogen, the timeframe of the interaction would be too short to observe an ISR effect; at least 4 days is generally allowed between application of the inducer and challenge with the pathogen $(30,51)$. In our assay, the disease rating takes place within that time period, before an ISR effect would be observable. Third, there was no effect of the bacteria when seedapplied. In that study, the bacteria were applied a few days before the pathogen, allowing conditions for ISR expression. Fourth, there was no effect of B. cepacia 1324 . Unless the mutant phenotype $\left(\right.$ antibiosis $^{-}$) is linked to the potential inducing agent of the systemic resistance, ISR would not likely be affected.

The similarity in root population size of $B$. cepacia AMMDR1 and B. cepacia 1324 indicates that their difference in effect on $A$. euteiches is probably due to the antibiosis ${ }^{-}$phenotype of the mutant and not to a difference in colonization capacity. Similarly, there was no evidence for a difference in endophytic populations between the two strains. Endophytic populations were small and unlikely to have any direct effect on the pathogen.

Treating peas with $B$. cepacia AMMDR1 led to a clear reduction in numbers of oogonia in the roots. To our knowledge, this is

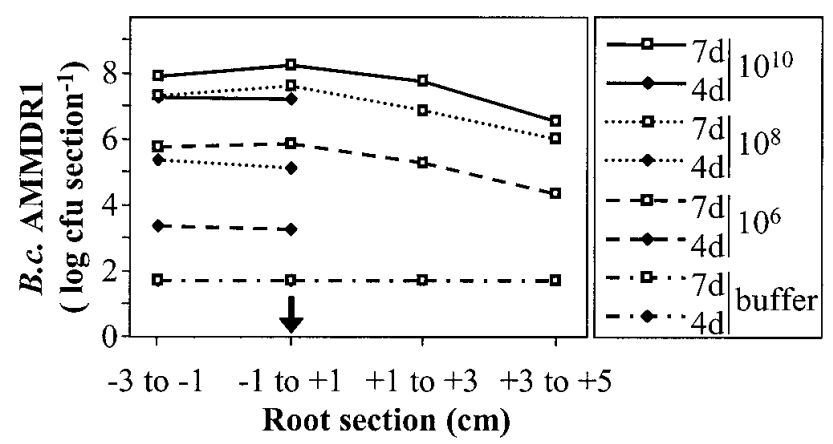

Fig. 4. Dose-response relationship between Burkholderia cepacia AMMDR1 populations on pea root sections 4 days after seeding $(4 \mathrm{~d}=$ time of bacterial inoculation) and 7 days after seeding ( $7 \mathrm{~d}=$ time of evaluation of lesion length) at different bacterial inoculation levels (none, $10^{6}, 10^{8}$, and $10^{10} \mathrm{CFU} \mathrm{ml}{ }^{-1}$ ). Data for the buffer control corresponded with the detection level (both days). Within each time and across sections, means for inoculation level were all significantly different $(P<0.001)$. the first report on the effect of a biocontrol agent on the formation of sexual reproductive structures of oomycetes. Interestingly, this occurred regardless of the method of bacterial inoculation (rootdip inoculated or seed applied). Formation of oogonia begins 4 days after inoculation with the pathogen, after the population of the biocontrol agent has reached high levels on those root sections where most oogonia production takes place. This area, a few centimeters above and below the zoospore inoculation site, shows lesions at the onset of oogonial production. Those tissues with lesions presumably provide plenty of nutrients for bacterial growth and ultimately support the largest population of B. cepacia AMMDR 1 along the root, approximately $10^{8} \mathrm{CFU} \mathrm{cm}{ }^{-1}$. The population size of other biocontrol agents also is larger on roots with lesions than on roots without lesions $(6,62)$. Production of many secondary compounds such as antibiotics is under the control of quorum sensors and stationary phase regulators such as $\mathrm{GacA}$, rpoS, or rpoD, and therefore, are stress or population density dependent $(48,50,54,56,57,64)$. Those conditions are present in the root lesions where most oogonia accumulate, suggesting the involvement of de novo antibiotic production in the reduction of oogonia production. Tissues with lesions may allow increased diffusion of the active component into the root cortex. Cross sections of roots in the area of zoospore inoculation revealed that the reduction in numbers of oogonia by $B$. cepacia AMMDR1 was most dramatic in the cortex and less so in the stele. This might reflect the difficulty with which the antibiotic diffuses across the endodermis. Further down the root, where the population of $B$. cepacia AMMDR1 is lower, and antibiotic production is likely to be less, the effect on oogonia is also reduced. This scenario of biological control through de novo antibiotic production in the zone of oogonia formation was supported by the experiment involving dip inoculation in decreasing concentrations of B. cepacia AMMDR1. There too, lower bacterial populations did not have an effect on lesion length but did reduce oogonia production. This is because the population size of $B$. cepacia AMMDR1 at the zone of oogonia production had become sufficiently large enough by that time to influence oospore formation.

Examples of postinfection biological control exist with other pathogens. For Gaeumannomyces graminis var. tritici it is hypothesized that phenazine-producing bacteria proliferate in primary lesions and use the increased exudation to produce more phenazines, thus restricting secondary spread and external growth of runner hyphae (49). Similarly, a Bacillus pumilus strain colonized roots more when they were infected with $G$. graminis (32). Also, the population density of Talaromyces flavus was increased on Verticillium-infected roots (6). However, presence of

TABLE 3. Aphanomyces euteiches lesion length and numbers of oogonia per root in a dose-response experiment involving dip-inoculation of infected seedlings in various concentrations of Burkholderia cepacia AMMDR1

\begin{tabular}{lccc}
\hline Treatment $^{\mathrm{v}}$ & $\begin{array}{c}\text { Total lesion } \\
\text { length }^{\mathrm{w}}\end{array}$ & $\begin{array}{c}\text { Total no. } \\
\text { of oogonia }\end{array}$ & $\begin{array}{c}\text { Oogonia per cm } \\
\text { of lesion }\end{array}$ \\
\hline Buffer & $55.3 \mathrm{a}$ & $30,552 \mathrm{a}$ & $5,816 \mathrm{a}$ \\
$10^{6} \mathrm{CFU} \mathrm{ml}^{-1}$ & $54.3 \mathrm{a}$ & $25,960 \mathrm{ab}$ & $4,917 \mathrm{ab}$ \\
$10^{8} \mathrm{CFU} \mathrm{ml}^{-1}$ & $53.2 \mathrm{a}$ & $20,872 \mathrm{~b}$ & $4,090 \mathrm{bc}$ \\
$10^{10} \mathrm{CFU} \mathrm{ml}^{-1}$ & $34.5 \mathrm{~b}$ & $10,704 \mathrm{c}$ & $3,355 \mathrm{c}$ \\
$P$ value $^{\mathrm{z}}$ & $<0.0001$ & $<0.0001$ & 0.013 \\
\hline
\end{tabular}

v Concentration of B. cepacia AMMDR1 in dip suspensions.

${ }^{w}$ Length of root (millimeter) showing water-soaked lesion, 4 days after zoospore inoculation. There were a minimum of 80 replicate roots per treatment.

${ }^{x}$ Number of oogonia per $8-\mathrm{cm}$ taproot, spanning $3 \mathrm{~cm}$ above the zoospore inoculation point to $5 \mathrm{~cm}$ below the zoospore inoculation point. There were five replicates consisting of 10 roots each.

y Number of oogonia per centimeter of lesion, using the data on lesion length from those roots used for oogonia counts.

${ }^{z}$ Observed $P$ values for test of equality of means analysis of variance. Within each column, means followed by the same letter are not significantly different $(P>0.05)$ according to least significant difference tests. 
the pathogen does not necessarily lead to an increase in antibiotic presence in the rhizosphere (60).

Our study on the effect of B. cepacia AMMDR1 on the sexual reproduction of $A$. euteiches at different times in the reproductive cycle required the use of oogonia and not oospores as the reproductive unit. Further studies should focus on the effect of $B$. cepacia AMMDR1 on the production and viability of oospores, because they are the structures that survive in soil. This will provide further information on the potential of B. cepacia AMMDR1 to interfere with the reproductive cycle of $A$. euteiches in the field. Our objectives required the application of the bacteria and the pathogen to specific parts of the roots at different times, without damaging the root system. As with any artificial system, the rolled towel system may have compromised some of the biological relevance with respect to field conditions. For example, proliferation of B. cepacia AMMDR1 may be more restricted on soil-grown roots than on those grown in paper towels. However, A. euteiches is mostly found in the upper layers of the soil and is especially pathogenic under conditions of high soil matric potential (41). $B$. cepacia AMMDR1 colonizes the upper parts of the root system under those conditions (20). Our data also suggest that B. cepacia AMMDR1 is competitive in root lesions, where oospore formation takes place. This indicates that $B$. cepacia AMMDR1 may have an effect on oospore production in the field. Nevertheless, this needs to be confirmed in experiments involving soil.

In contrast with the effect on sexual reproductive structures, $B$. cepacia AMMDR1 had no effect on the production of secondary zoospore inoculum in our assay. The reason for this lack of effect may have been because $B$. cepacia AMMDR1 cannot affect the active mycelium inside the root at this stage. The sporangia are extruded straight out of the root and make little contact with the root surface where the bacteria reside. Also, the protocol used to induce sporangial release involved immersion in water, which may have diluted the active bacterial components beyond a level where they could have an effect on sporangia. Conditions for zoospore production in soil also would involve periods of (near) saturation. However, the volume of water surrounding the root would be much smaller in soil. In our assay, production of secondary zoospores was highly variable, but usually thousands of spores were generated from individual roots, almost exclusively from the region with actively growing mycelium. To our knowledge, this is the first quantitative data on the production of $A$. euteiches zoospores from infected roots. These numbers are higher than those observed for Phytophthora fragariae and Phytophthora capsici $(27,40)$, the only oomycetes for which such quantitative data is available. There is no information available on the role and importance of A. euteiches secondary zoospore production in situ, but it may be involved in plant-to-plant secondary dispersal (46).

In conclusion, this work demonstrates that B. cepacia AMMDR1 can restrict an ongoing Pythium infection of seeds and reduce mycelial growth and the production of A. euteiches oogonia. All effects were dependent on the application or the in situ production of antibiotics at the site of pathogen activity. Therefore, a formulation of the biocontrol agent that includes some of its antibiotic would provide immediate protective effects, which can be crucial for fast-attacking pathogens such as Pythium. The biocontrol agent itself may not only contribute to preinfection control but could have an active role in postinfection control through in situ production of the antibiotic, as indicated here through its effects on oogonia. This work demonstrates that the population size of $B$. cepacia AMMDR1 and most likely the in situ production of antibiotics depends on the interaction between the host and the pathogen, illustrating the importance of the ecology of the different organisms in the system. These findings also demonstrate that biocontrol agents may have considerable effects that are not immediately noticeable, such as reduction of pathogen survival structures.
Considerable concern about intentional agricultural application of $B$. cepacia has arisen recently (8) because some strains of the $B$. cepacia complex have been linked to lung infections in individuals with cystic fibrosis. Until differentiation between biocontrol strains and human pathogenic strains is possible, an alternative approach to utilizing the biocontrol capability of this organism may be to identify the genes in B. cepacia AMMDR1 responsible for antibiosis and transfer them into a more benign rhizoplanecolonizing bacterium such as Pseudomonas fluorescens. The data presented in this work demonstrate that most of the biocontrol effect by this strain results from antibiosis and suggests that this is, therefore, a promising approach.

\section{ACKNOWLEDGMENTS}

This work was supported by a grant from the U.S. Department of Agriculture Competitive Grants Program in Biologically Based Pest Management (grant 98-35316-6480) and the College of Agriculture and Life Sciences at the University of Wisconsin-Madison. We thank the StorkanHanes Foundation for additional financial support of K. Heungens, and C. Grau for helpful discussions.

\section{LITERATURE CITED}

1. Atlas, R. M. (ed.) 1997. Handbook of Microbiological Media. 2nd ed. CRC Press, Boca Raton, FL.

2. Battershill, J. M., and Fielder, R. J. 1998. Mouse-specific carcinogens: An assessment of hazard and significance for validation of short-term carcinogenicity bioassays in transgenic mice. Hum. Exp. Toxicol. 17:193-205.

3. Bowers, J. H., and Parke, J. L. 1993. Epidemiology of Pythium damping-off and Aphanomyces root rot of peas after seed treatment with bacterial agents for biological control. Phytopathology 83:1466-1473.

4. Coenye, T., Mahenthiralingam, E., Henry, D., LiPuma, J., and Vandamme, P. 2000. Classification of Burkholderia cepacia-like biocontrol strains and strains isolated from CF patients as a new member of the B. cepacia complex. (Abstr.) Pediatr. Pulmonol. 30(suppl.):S20.

5. Davis, D. W., Fritz, V. A., Pfleger, F. L., Percich, J. A., and Malvick, D. K. 1995. MN 144, MN 313, and MN 314: Garden pea lines resistant to root rot caused by Aphanomyces euteiches Drechs. HortScience 30:639-640.

6. Fahima, T., and Henis, Y. 1995. Quantitative assessment of the interaction between the antagonistic fungus Talaromyces flavus and the wilt pathogen Verticillium dahliae on eggplant roots. Plant Soil 176:129-137.

7. Flentje, N. T. 1964. Pre-emergence rotting of peas in South Australia, II. Factors associated with the soil. Aust. J. Biol. Sci. 17:651-664.

8. Govan, J. R., Balendreau, J., and Vandamme, P. 2000. Burkholderia cepacia-Friend and foe. ASM News 66:124-125.

9. Grau, C. R. 1977. Effect of dinitramine and trifluralin on growth, reproduction, and infectivity of Aphanomyces euteiches. Phytopathology 61:551-556.

10. Hagedorn, D. J. 1984. Compendium of Pea Diseases. The American Phytopathological Society, St. Paul, MN.

11. Hallmann, J., Quadt-Hallmann, A., Mahaffee, W. F., and Kloepper, J. W. 1997. Bacterial endophytes in agricultural crops. Can. J. Microbiol. 43:895-914.

12. Harman, G. E. 1984. Seed and seedling diseases: diseases caused by Pythium spp. Pages 5-6 in: Compendium of Pea Diseases. D. J. Hagedorn, ed. The American Phytopathological Society, St. Paul, MN.

13. Harvey, R. G., Hagedorn, D. J., and DeLoughery, R. L. 1975. Influence of herbicides on root rot in processing peas. Crop Sci. 15:67-71.

14. Heungens, K., and Parke, J. L. 2000. Zoospore homing and infection events: Effect of the biocontrol bacterium, Burkholderia cepacia AMMDR1 on two oomycete pathogens of pea. Appl. Environ. Microbiol. 66:5192-5200.

15. Heungens, K. K. 1999. Pre- and post-infection interactions between the biocontrol agent Burkholderia vietnamiensis AMMDR1 and oomycete pathogens of pea. Ph.D. thesis. University of Wisconsin, Madison.

16. Howell, C. R. 1991. Biological control of Pythium damping-off of cotton with seed-coating preparations of Gliocladium virens. Phytopathology 81:738-741.

17. Kazmar, E. R. 1995. The effect of intercropped oats on Aphanomyces root rot of pea. M.S. thesis. University of Wisconsin, Madison.

18. Kempf, H. J., Scheffer, R. J., and Ligon, J. 1997. Examples of Novartis research activities regarding the use of bacteria in disease control. Proc. Int. Workshop Plant Growth-Promoting Rhizobacteria, 4th. A. Ogoshi, K. Kobayashi, Y. Homma, F. Kodama, N. Kondo, and S. Akino, eds. 
Sapporo, Japan.

19. King, E. B., and Parke, J. L. 1993. Biocontrol of Aphanomyces root rot and Pythium damping-off by Pseudomonas cepacia AMMD on four pea cultivars. Plant Dis. 77:1185-1188.

20. King, E. B., and Parke, J. L. 1996. Population density of the biocontrol agent Burkholderia cepacia AMMDR1 on four pea cultivars. Soil Biol. Biochem. 28:307-312.

21. Kjøller, R., and Rosendahl, S. 1997. Polyacrylamide gel electrophoresis (PAGE) and densitometric measurement of enzyme activity of the pea root pathogen Aphanomyces euteiches in pea roots. J. Phytopathol. 145:253-256.

22. Kraft, J. M. 1989. Registration of 86-638, 86-2197, 86-2231, and 862236 pea germ plasm. Crop Sci. 29:494-495.

23. Kraft, J. M. 1992. Registration of 90-2079, 90-2131, and 90-2322 pea germ plasms. Crop Sci. 32:1076.

24. Kraft, J. M., and Boge, W. L. 1996. Identification of characteristics associated with resistance to root rot caused by Aphanomyces euteiches in pea. Plant Dis. 80:1383-1386.

25. Kraft, J. M., Haware, M. P., Jimenez Diaz, R. M., Bayaa, B., and Harrabi, M. 1993. Screening technique and sources of resistance to root rots and wilts in cool season food legumes. Euphytica 73:27-39.

26. Kraus, J., and Loper, J. E. 1995. Characterization of a genomic region required for production of the antibiotic pyoluteorin by the biological control agent Pseudomonas fluorescens Pf-5. Appl. Environ. Microbiol. 61:849-854.

27. Law, T. F., and Milholland, R. D. 1991. Production of sporangia and oospores of Phytophthora fragariae in roots of strawberry plants. Plant Dis. 75:475-478.

28. Lewis, M. E., and Gritton, E. T. 1992. Use of one cycle of recurrent selection per year for increasing resistance to Aphanomyces root rot in peas. J. Am. Soc. Hortic. Sci. 117:638-642.

29. Lifshitz, R., Windham, M. T., and Baker, R. 1986. Mechanism of biological control of preemergence damping-off of pea by seed treatment with Trichoderma spp. Phytopathology 76:720-725.

30. Liu, L., Kloepper, J. W., and Tuzun, S. 1995. Induction of systemic resistance in cucumber against bacterial angular leaf spot by plant growth-promoting rhizobacteria. Phytopathology 85:843-847.

31. Malvick, D. K., Grau, C. R., and Percich, J. A. 1998. Characterization of Aphanomyces euteiches strains based on pathogenicity tests and random amplified polymorphic DNA analyses. Mycol. Res. 102:465-475.

32. Maplestone, P. A., and Campbell, R. 1989. Colonization of roots of wheat seedlings by bacilli proposed as biocontrol agents against take-all. Soil Biol. Biochem. 21:543-550.

33. Martin, F. N., and Loper, J. E. 1999. Soilborne plant diseases caused by Pythium spp.: Ecology, epidemiology and prospects for biological control. Crit. Rev. Plant Sci. 18:111-181.

34. Meister, R. T. 1999. Farm Chemicals Handbook '99. Vol. 85. Meister Publishing Company, Willoughby, $\mathrm{OH}$.

35. Morton, H. V., and Urech, P. A. 1989. History of the development of resistance to phenylamide fungicides. Pages 59-60 in: Fungicide Resistance in North America. C. J. Delp, ed. The American Phytopathological Society, St. Paul, MN.

36. Muehlchen, A. M., Rand, R. E., and Parke, J. L. 1990. Evaluation of crucifer green manures for controlling Aphanomyces root rot of peas. Plant Dis. 74:651-654.

37. National Research Council 1987. Regulating Pesticides in Food-The Delaney Paradox. National Academy Press, Washington, D.C.

38. O'Brien, T. P., and McCully, M. E. 1981. The Study of Plant Structure: Principles and Selected Methods. Termarcarphi, Melbourne, Australia.

39. Olsen, R. H., and Shipley, P. 1973. Host range and properties of the Pseudomonas aeruginosa R factor R1822. J. Bacteriol. 113:772-780.

40. Palloix, A., Daubeze, A. M., and Pochard, E. 1988. Time sequence of root infection and resistance expression in an artificial inoculation method of pepper with Phytophthora capsici. J. Phytopathol. 123:12-24.

41. Papavizas, G. C., and Ayers, W. A. 1974. Aphanomyces species and their root diseases in pea and sugarbeet: A review. U.S. Dep. Agric. Tech. Bull. 1485 .

42. Parke, J. L. 1990. Population dynamics of Pseudomonas cepacia in the pea spermosphere in relation to biocontrol of Pythium. Phytopathology
80:1307-1311

43. Parke, J. L., Rand, R. E., Joy, A. E., and King, E. B. 1991. Biological control of Pythium damping-off and Aphanomyces root rot of peas by application of Pseudomonas cepacia or P. fluorescens to seed. Plant Dis. 75:987-992.

44. Payne, P. A., and Williams, G. E. 1990. Hymexazol treatment of sugarbeet seed to control seedling disease caused by Pythium spp. and Aphanomyces cochlioides. Crop Prot. 9:371-377.

45. Persson, L., Bodker, L., and Larsson Wikstrom, M. 1997. Prevalence and pathogenicity of foot and root rot pathogens of pea in southern Scandinavia. Plant Dis. 81:171-174.

46. Pfender, W. F., and Hagedorn, D. J. 1983. Disease progress and yield loss in Aphanomyces root rot of peas. Phytopathology 73:1109-1113.

47. Phillips, J. M., and Hayman, D. S. 1970. Improved procedures for clearing roots and staining parasitic and vesicular-arbuscular mycorrhizal fungi for rapid assessment of infection. Trans. Brit. Mycol. Soc. 5:158-161.

48. Pierson, L. S., III, Keppenne, V. D., and Wood, D. W. 1994. Phenazine antibiotic biosynthesis in Pseudomonas aureofaciens 30-84 is regulated by $P h z R$ in response to cell density. J. Bacteriol. 176:3966-3974.

49. Pierson, L. S., III, and Pierson, E. A. 1996. Phenazine antibiotic production in Pseudomonas aureofaciens: Role in rhizosphere ecology and pathogen suppression. FEMS Microbiol. Lett. 136:101-108.

50. Pierson, L. S., Wood, D. W., and Pierson, E. A. 1998. Homoserine lactone-mediated gene regulation in plant-associated bacteria. Annu. Rev. Phytopathol. 36:207-225.

51. Pieterse, C. M. J., Van Wees, S. C. M., Hoffland, E., Van Pelt, J. A., and Van Loon, L. C. 1996. Systemic resistance in Arabidopsis induced by biocontrol bacteria is independent of salicylic acid accumulation and pathogenesis-related gene expression. Plant Cell 8:1225-1237.

52. Regner, K. M. 1996. The role of pyrrolnitrin in the suppression of damping-off of Burkholderia cepacia AMMD. Ph.D. thesis. University of Wisconsin, Madison.

53. Ruiz, M. J., and Marzin, D. 1997. Genotoxicity of six pesticides by Salmonella mutagenicity test and SOS chromotest. Mutat. Res. 390: 245-255.

54. Sacherer, P., Défago, G., and Haas, D. 1994. Extracellular protease and phospholipase $\mathrm{C}$ are controlled by the global regulatory gene gacA in the biocontrol strain Pseudomonas fluorescens CHA0. FEMS Microbiol. Lett. 116:155-160.

55. Sanders, P. L. 1984. Failure of metalaxyl to control Pythium blight on turfgrass in Pennsylvania. Plant Dis. 68:776-777.

56. Sarniguet, A., Kraus, J., Henkels, M. D., Muehlchen, A. M., and Loper, J. E. 1995. The sigma factors $\sigma^{\mathrm{s}}$ affects antibiotic production and biological control activity of Pseudomonas fluorescens Pf-5. Proc. Natl. Acad. Sci. USA 92:12255-12259.

57. Schnider, U., Keel, C., Blumer, C., Troxler, J., Défago, G., and Haas, D. 1995. Amplification of the housekeeping sigma factor in Pseudomonas fluorescens $\mathrm{CHA} 0$ enhances antibiotic production and improves biocontrol abilities. J. Bacteriol. 177:5387-5392.

58. Smolinska, U., Knudsen, G. R., Morra, M. J., and Borek, V. 1997. Inhibition of Aphanomyces euteiches f. sp. pisi by volatiles produced by hydrolysis of Brassica napus seed meal. Plant Dis. 81:288-292.

59. Snedecor, G. W., and Cochran, W. G. 1989. Statistical Methods, 8th ed. Iowa State University Press, Ames, IA.

60. Thomashow, L. S., Weller, D. M., Bonsall, R. F., and Pierson, L. S., III. 1990. Production of the antibiotic phenazine-1-carboxylic acid by fluorescent Pseudomonas species in the rhizosphere of wheat. Appl. Environ. Microbiol. 56:908-912.

61. Vincelli, P. C. 1992. Potential for seedling disease of alfalfa caused by Aphanomyces euteiches in a Kentucky soil. Plant Dis. 76:622-626.

62. Weller, D. M. 1983. Colonization of wheat roots by a fluorescent pseudomonad suppressive to take-all. Phytopathology 73:1548-1553.

63. Whipps, J. M., and Lumsden, R. D. 1991. Biological control of Pythium species. Biocontrol Sci. Technol. 1:75-90.

64. Whistler, C. A., Corbell, N. A., Sarniguet, A., Ream, W., and Loper, J. E. 1998. The two-component regulators GacS and GacA influence accumulation of the stationary-phase sigma factor $\sigma^{\mathrm{s}}$ and the stress response in Pseudomonas fluorescens Pf-5. J. Bacteriol. 180:6635-6641. 